\title{
Perceived Trust of E-Services, Perceived Usefulness and Adoption of E-Banking amongst the Students of University of Kelaniya: A Relational Study
}

\author{
D.A.G. Nayanajith \\ University of Kelaniya
}

D.M.R. Dissanayake

University of Kelaniya

\section{R.A.S. Weerasiri}

University of Kelaniya

\section{K.A. Damunupola}

University of Uva Wellassa

\begin{abstract}
This study examines the relationship of perceived usefulness and perceived trust of e-services on adopting e-banking in the context of Sri Lankan private commercial banks. Sample was drawn from the students of University of Kelaniya, those who are possessing e-banking facilities of private banks. Initially 500 questionnaires were distributed and 305 duly completed questionnaires were considered for the final data analysis process. Governing factors on perceived trust of e-services were identified by conducting principal component analysis. TAM has been extended by using the perceived trust of e-services. In order to test the hypotheses, correlation analysis followed by multiple regression analysis using hierarchical method along with diagnosis tests for outliers, residuals, influential cases, were performed whilst supplementary statistical tests, such as trend analysis and contrast test of ANOVA were also used for further analysis of demographic characteristics with
\end{abstract}


special reference to respondents' income levels. The empirical evidence supported two hypotheses indicating the positive relationships of perceived trust of e-services and perceived usefulness variables towards e-banking adoption. Furthermore, it was revealed that there are differences in adoption of e-banking with regard to several demographic variables. Third hypothesis stating the existence of differences in adoption of e-banking between lower income category customers and higher income category was also supported. Restricted sample selection and time restrictions are limitations. Nevertheless, extending of TAM in relation to present research context could be noted as the originality of the research. Findings would be beneficial for Sri Lankan bankers and banking application developers, alike. In conclusion, future research could be conducted in varied contexts in the field of technology adoption in search of novel findings.

\section{Key words}

E-banking; Internet banking; Perceived trust; Perceived usefulness; Sri Lanka

\section{Introduction}

Susceptibility of the country's economy to both global and local disturbances was visible in the recent past as shown by the macroeconomic and sustainable development indicators. Services sector of Sri Lanka contributes most to the economy where services related economic activities expanded by 4.7 per cent in 2018 in value added terms (CBSL, 2019). The progression of service sector activities during the year was supported by the development in financial services activities together with the expansions in wholesale and retail trade activities without causing significant macro-prudential concerns amid critical market conditions. The banking sector continued to steer the financial sector, accounting for considerable 72.5 per cent of the total assets of the financial sector and its performance persisted robust during 2018 while maintaining satisfactory capital and liquidity thresholds over and above the stipulated regulatory minimum levels. Sri Lankan banking sector comprised of 26 Licensed Commercial Banks (LCBs), including 13 branches of foreign commercial banks and 7 Licensed Specialized Banks (LSBs) as of end of the year 2018 (CBSL, 2019). Nevertheless, the profitability of the banking sector has deteriorated due to the escalation of operating expenses, among other things. Hence, this could be addressed by minimizing operational expenditures while improving other income sources simultaneously by facilitating electronic onboarding while promoting electronic banking services all together. 
Electronic banking is the presentment of retail and wholesale banking over the internet channel which encompasses both of individual and corporate clients (Aladwani, 2001; UNCTAD, 2002 as cited by Narware, 2016 \& Rajapakse, 2017). Meihami, Varmaghani and Meihami (2013) noted that by means of plummeting operational costs, banks could improve the overall income generated by ebanking. Continuous innovations in banking industry can be easily replicated, thus making it difficult to sustain a leading edge over the contenders in the industry (Lymperopoulos \& Chaniotakis, 2005). Chavan (2013) stated that a lot of consumers in some of the developing countries either do not believe in or do not have the required access to the necessary infrastructure to be competent to process e-payments.

Various research studies highlighted that in the Sri Lankan context, e-banking acceptance is at an insignificant level excluding ATM usage (Abeyrathna, 2015; Premarathne \& Gunatilake 2016; Kariyawasam \& Jayasiri 2015). Customers visit bank counters for numerous transactions notwithstanding the fact that they could perform such transactions electronically (Hettiarachchi 2013). Weerasekara \& Abeygunawardhana (2011) identified that usage of electronic banking is comparatively very slow in considering increasing internet usage. Whereas the banking apex institution's report noted that "With continual improvements in technology and consumers' increasing reliance on it, changes to delivery of banking products are likely to happen more efficiently and effectively" (CBSL, 2018, p.257). Although most of the researchers stated that Sri Lankan e-banking adoption is not at high level, uppermost systematically important commercial banks have identified that there is a higher growth in e-channels which sometimes reported an exponential growth (Sampath bank annual report 2018; Commercial bank of Ceylon annual report 2018; HNB annual report 2018). This research makes a contribution to both the theory and practice perspectives on adoption of e-banking, particularly in the developing country's private commercial banks' perspective by incorporating interrelated models on technology adoption.

Comparative studies investigate e-banking adoption by concentrating on comparisons among key variables. These key variables can be represented by three groups of studies: population, distribution channel and methods (Hanafizadeh et al., 2014). Similarly, this study does not compare e-banking adoption from the perspectives of customers and institutions (bank), various country perspectives and comparisons taking account of usability, reliability, 
functionality etc. (Sayar \& Wolfe, 2007). Also, comparison of e-banking adoption by customers of different types of banks (governmental and private banks) with respect to political, economic and other variables, was also not been considered (Mirza et al., 2009). Instead, this study primarily pursues to understand how the different factors (such as trust of e-services, perceived usefulness) affect ebanking adoption in the given context (Hanafizadeh et al., 2014). In line with that, present study attempts to explain the e-banking adoption phenomenon from the customers' perspective using the related models and theories pertinent to new technology adoption and social psychology, incorporating technology acceptance model and commitment-trust theory (Davis, 1989; Nayanajith \& Dissanayake, 2019; Hanafizadeh et al., 2014; Morgan \& Hunt, 1994).

Besides identifying the effect of perceived trust of e-services (PTES) on adopting e-banking, this study assists management of commercial banks and other stakeholders, regulators and policy makers indifferently, to address retail customers' perceptions and create mutually beneficial relationship for the betterment of the overall financial services industry and service sector in Sri Lanka. As the banking is one of the leading industry in the service sector, PTES is of utmost importance and the investment directed on trust building initiatives can be executed with a greater confidence upon the exact determination of the precise relationship of constructs and adoption of e-banking given the intensified importance of trust, confidence and risk of threats on e-service platforms due to challenges in managing sensitive public data and information. Research article initially discusses the present context of the e-banking and theoretical background of related concepts. Afterwards, article is continued whilst presenting hypotheses and the methodology. Subsequently, results of the statistical analysis of data are illustrated succeeding the methodology section. Discussion of the results is arranged and presented prior to the last section and the article concluded with recommendations and directions for future research.

\section{Rationale for the Research Problem}

Examining the factors influencing e-banking adoption in less-developed regions, particularly in some parts of Africa and Asia with particular consideration for the specific demographic aspects of these regions, has been recognized as one of the important research opportunities for future research (Hanafizadeh et al., 2014; Roy et al., 2017; Samar et al., 2017). Correspondingly, numerous researchers have recognized the strategic significance of conducting research on the phenomenon of e-banking adoption related to various emerging and developing 
country perspectives (Afshan et al., 2018; Nayanajith \& Dissanayake, 2019; Rahi, 2015).

Retention of public trust while providing safe and secured financial services, is vital for the proper functioning of market mechanism (CBSL, 2019). Timely addressing of various aspects of risks, embed innovation, service quality enhancement and secure services provision, are paramount in improving the internet banking adoption level within Sri Lankan banking context (Commercial Bank of Ceylon, 2019; HNB PLC, 2019; Sampath Bank PLC, 2019). Moreover, several researchers have noted the significance of perceived trust and perceived usefulness aspects in relation to the adoption of e-banking within different country contexts (Al-Sharafi et al., 2016; Damghanian et al., 2016; Roy et al., 2017).

Almost all the systemically important leading private commercial banks have noted that there is a substantial increase in utilizing electronic/digital service facilities which includes consumer e-banking services (Commercial Bank of Ceylon, 2019; HNB PLC, 2019; Sampath Bank PLC, 2019). Nevertheless, researchers have highlighted that adoption of electronic banking services among Sri Lankans, is not at a satisfactory level where most of them prefer traditional over the counter banking transactions despite the fact that they are aware of ebanking services.

Most of the local research studies have conducted the researches in view of identifying the factors affecting the adoption of e-banking, in which they have identified that perceived ease of use, perceived usefulness, perceived trust, perceived risk and several demographic variables are significant determinants, inter alia; in adopting e-banking (Priyangika et al., 2016; Rajapakse, 2017). However, banking regulator of Sri Lanka has noted that maintenance of higher trustworthiness standards, is paramount in delivering the useful and essential financial services to retain public trust (CBSL, 2019). Therefore, present study has formulated the research problem as follows,

What is the relationship of perceived trust of e-services, perceived usefulness and income level differences in adopting e-banking services offered by leading commercial banks in Sri Lanka?

Accordingly, the research objectives are as follows, 
Primary objective of the present research study is to identify whether there is a positive relationship of PU and PTES towards adoption of e-banking services offered by private commercial banks operating in Sri Lanka.

Secondary objective is to identify whether there is a difference in adoption of ebanking services between lower income category customers and higher income category customers.

\section{Literature Review}

\section{Theoretical Perspective}

Technology Acceptance Model (TAM) is an extension of Ajzen and Fishbein's theory of reasoned action (TRA). Davis's TAM (Davis, 1989; Davis, Bagozzi, \& Warshaw, 1989) is applied extensively to understand user adoption and usage of technology (Venkatesh, 2000). TAM was developed by Fred Davis and Richard Bagozzi (Davis 1989; Bagozzi, Davis \& Warshaw 1992). TAM is an adaptation of TRA for information systems field. TAM was originally used to examinee-banking adoption by Bhattacherjee (2001). His research examined a post-acceptance application of TAM to understand the role of expectations in ebanking adoption and continued usage amongst United States banking customers. Other remarkable application of TAM in the study of internet banking adoption was presented by Suh and Han (2002 \& 2003) who were the first to consider cross-national effects in their study of South Korean online banking customers. Another prominent study was conducted by Vatanasombut, Igbaria, Stylianou and Rodgers (2008) integrating TAM and CTT to understand continuance intentions. Numerous attempts to extend TAM (e.g., TAM2) have generally guided largely by one of the following 3 approaches: by incorporating factors from interconnected models on customer adoption, by means of integrating additional or alternative belief factors, and lastly by examining antecedents and moderators of PU and PEOU.

\section{Adoption of E-Banking, Perceived Usefulness and Trust of E-Services}

Perceived usefulness, trust and the government support all positively associated with the intention towards usage of online banking and in contrast to the technology acceptance model, perceived ease of use was found to be not significant in the study (Chong, Ooi, Lin \& Tan, 2010). Privacy, security and convenience factors play significant role in determining user adoption of e-banking services in relation to different segmentations on age groups, education levels and income levels (Poon, 2007). The barriers to adoption 
were mostly the lack of awareness and understanding of the benefits of the mobile banking operations in the context of China (Laforet \& Li, 2005). Wang, Cho and Denton (2017) indicated that customization/personalization of e-banking services results in increasing intention to continuation. Arun, Kaushik and Rahman (2015) recognized that adopter attitudes differ across different types of self-service banking technologies. Utilitarian orientation of the particular bank's website instead of hedonic orientation of the bank has significant effect on adoption of e-banking (Ndubisi \& Sinti, 2006). Lassar, Manolis and Lassar, (2005) suggested type of the consumer innovation affects in understanding the adoption of e-banking. Innovativeness and the perceived technology security were important; among other factors, for user intention on adoption of e-banking (Rahi \& Ghani, 2018; Nayanajith, 2019; Nayanajith \& Dissanayake, 2019). Gerrard and Cunningham (2003) suggested in internet banking, adopters were found to be reasonably financially innovative whereas social desirability, confidentiality, accessibility and economic benefits were observed with indifference when adopters were matched with non-adopters.

In a research study conducted in Finland in the light of the technology acceptance model (TAM) by Pikkarainen et al. (2004) proposed that online banking adoption or acceptance can be modeled with the TAM variables perceived usefulness and perceived ease of use (PU \& PEOU) with four other variables referred as perceived enjoyment (PE), information on online banking, security and privacy, and the quality of the internet connection variables as derived from the available online banking acceptance literature. The study conducted by Priyangika, Perera and Rajapakshe (2016) mainly focused on the analysis of customers' attitude towards internet banking under four factors (TAM with two additional factors); PEOU, PU, perceived risk (PR) and subjective norms (SN). Attitude towards online banking has strong positive relationships with PEOU and PU while PR and the SN have weak positive relationships. Some researchers using extended TAM with moderators indicated that perceived usefulness, perceived ease of use, security, social facet and the perceived system quality were found to be the most influential factors explaining the accepting or adoption of e-banking services (Jayasiri, Gunawardana \& Dharmadasa, 2015; Nayanajith et al., 2019a).

Yousafzai, Foxall and Pallister (2010) suggested that TAM is superior in comparison to both the TRA and TPB in explaining the variance in actual behavior and also in terms of model fit, specifically in an internet banking context. TAM outperformed both the TRA and the TPB and explanation could be the 
TAM's usage of two specific beliefs (PU and PEOU), which can be applied across any kind of technology acceptance context (Nayanajith \& Damunupola, 2020a \& 2020b). Chiou and Shen (2012) noted in their research performed in Taiwan that the researchers utilized the constructs derived from various sources including the transaction cost analysis (TCA), TAM and relationship marketing literature. Roy, Balaji, Kesharwani and Sekhon (2017) pointed out that TAM and perceived risk theory (PRT) supported for both the extended TAM research model and the hypotheses regarding the relationships between perceived risk, PU, PEOU, attitude and behavioral intentions regarding internet banking in Indian context.

Several researchers pointed out that trust has a positive effect on behavioral intention to use e-banking services as its usefulness, security and privacy perceptions significantly influenced the perceived trust (Al-Sharafi, Arshah, AboShanab \& Elayah, 2016). Normalini and Ramayah (2017) revealed that although there was an insignificant relationship between perceived privacy and trust; perceived biometrics effectiveness significantly influenced the strength of the relationships between both perceived privacy and perceived security with trust. Perceived costs, quality of infrastructure, privacy, security and disposition to trust were barriers to non-users' intentions towards engaging in any online financial transactions. (Chiu, Chiu \& Mansumitrchai, 2016). Another research result mainly indicated that behavioral intention is significantly and positively influenced by performance expectancy, effort expectancy, hedonic motivation, price value and trust in Jordanian context (Alalwan, Dwivedi \& Rana, 2017).

The initial trust directly affects the user sense of experience of mobile banking and decides the tendency of trust, which affects the actual use. For that reason, the mobile phone banks need to pay more attention to the initial sense of trust and experience to promote user acceptance and trust mobile banking services (Sun, Sun, Liu \& Gui, 2017). Non-adopters of mobile banking asserted that the antecedents of initial trust played a significant influence on behavioral intention to use online banking services (Chiu, Bool \& Chiu, 2017). Customer trust and experience demonstrate a significant relationship towards adoption of different kinds of e-services (Nayanajith et al., 2019b).

Trust positively affected customers' behavioral intention towards adopting ebanking services. Moreover, the customer perception, including their PU, security and privacy had a significant impact on customers' trust. (Al-Sharafi, Arshah, Herzallah \& Abu-Shanab, 2018). Moreover, several Sri Lankan research studies 
have revealed that PU, PEOU, perceived security and trust of e-services, SN predictor variables could be used in conjunction with moderators and covariates, in analyzing the e-banking adoption phenomena (Nayanajith \& Damunupola 2019a \& 2019b; Nayanajith \& Damunupola, 2019).

\section{Hypotheses of the Study}

Jayasiri et al. (2015) found that among other factors, PEOU and PU are among two of the most influential factors that describe the e-banking adoption in Sri Lanka. Another research effected by Deb and David (2013) found empirical evidence for positive relationship between PU, PEOU and societal influence on positive attitude towards mobile banking in Indian context. In a subsequent study conducted on adoption of e-banking by Rakesh and Ramya (2014) have identified experimental evidence for positive relationship in between PU, PEOU and social influence on positive attitude towards mobile banking in the context of India. Similarly, several researchers have noted the significant factors as PU, PEOU and some few other factors on adoption of banking technology and such other technologies (Lee \& Lai, 2007; Masoud \& Abu Taqa, 2017; Montazemi \& QahriSaremi, 2015; Nayanajith et al., 2019c). Another study in UAE steered by Aboelmaged and Gebba (2013) pointed out that the regression results shown a significant impact of PU on attitude towards mobile banking adoption while the influence of PEOU on attitude towards mobile banking has not been supported. Considering the aforesaid facts following hypothesis is proposed,

H1-There is a positive relationship of PU and adoption of e-banking

Certain researchers claimed that the variables of perceived security and trust in ebanking had a significantly positive impact on the adoption of e-banking. (Damghanian et al., 2016). The relationship between trust and behavioral intention are positively significant (Dayal et al., 1999; Gefen, 2000; Wang et al., 2015). Customer trust and experience have significant relationship towards adoption of online banking (De Leon, 2019; Malaquias \& Hwang, 2016; Mayer et al., 1995; Selvanathan et al.,2016). Trust significantly and positively impacts commitment. Mobile banking service quality dimensions also influence trust and commitment. Trust is associated with security, privacy and practicity: regarded as utilitarian factors, while commitment is driven by enjoyment and sociality: dimensions more hedonic by nature (Arcand et al., 2017; Hoffman et al., 1999). Considering the aforementioned facts following hypothesis is proposed, 
$\mathrm{H} 2$-There is a positive relationship of PTES and adoption of e-banking

Privacy, security and convenience factors demonstrate significant role in determining users' adoption of e-banking in relation to different segmentations on age groups, education levels and income levels (Poon, 2007). Kolodinsky (2004) found that income, assets, education, gender and marital status and age also affect e-banking adoption by Americans. Adoption changed over time, but the impact of other factors on adoption has not changed. Odumeru (2012) showed that acceptance of e-banking in Nigeria is significantly influenced by age, educational background, income, perceived benefits, PEOU, perceived risk and perceived enjoyment. The attributes related to demographic factors such as: gender, age, educational level, and monthly income were significantly influential variables on internet banking (Sivapragasam \& Pieris, 2014 as cited by Rajapakse, 2017). Studies have also revealed that there is a moderate impact of demographics such as respondents' age, income levels and working hours (Rajapakse, 2017). There are differences between demographic variables viz. age, income, education, occupation, banking experience and adoption of electronic banking. Further, comprehensive analysis recorded that consumer e-banking acceptance is greater for the high-profile long-standing customers with higher job positions (Nayanajith \& Damunupola, 2019; Nayanajith \& Damunupola, 2019b). Likewise, several researchers identified that younger generation who are more computer literate are more likely to adopt internet banking whilst identifying significant differences in considering income levels and education levels in general, inter alia (Ba \& Pavlou, 2002; Premaratne \& Gunathilaka, 2016; Priyangika et al., 2016; Weerasekara \& Abeygunawardhana, 2011). Considering the aforementioned facts following hypothesis is proposed,

H3-There is a difference in adoption of e-banking between lower income category customers and higher income category customers

\section{Conceptual Framework}

Based on the above discussion of the literature following conceptual model (Figure 1) was formulated for the study. 
Figure 1: Conceptual model

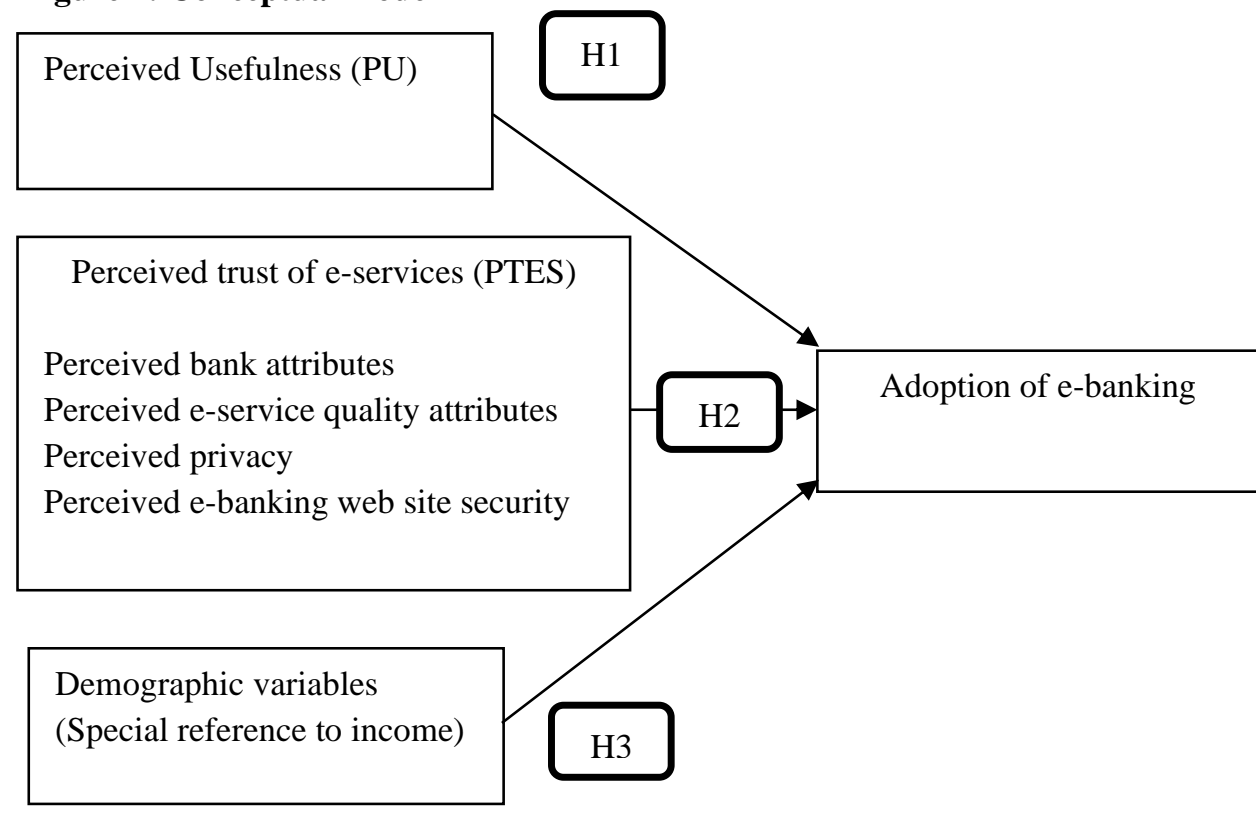

\section{Research Method}

In this study quantitative approach has been used. Survey method is used here and the structured questionnaire is the data collection technique. Saunders (2011) specified that questionnaires can be utilized to examine and explain relationships between variables. The students those who possess e-banking facilities of private banks from the University of Kelaniya, one of the national universities in Sri Lanka are selected as the sample of the study employing convenient sampling. Initially 500 questionnaires were distributed and 305 duly (61\% response rate) completed questionnaires were considered for the final data analysis process. The variables in the conceptual model is measured using the scales given in Table 1.

Table 1: Summary of Measurement Scales

\begin{tabular}{lll}
\hline Variable & No. of Items & Source \\
\hline PU & 10 & Davis, 1989; Nayanajith et al., 2019d \\
PTES & 24 & Al-Sharafi et al., 2018; \\
& Al-Sharafi et al., 2016; Morgan \& Hunt, \\
& 1994; Rotter, 1967; Rousseau et al., 1998; \\
& Sekhon et al., 2010; Wang et al., 2015; \\
& Yousafzai et al., 2003
\end{tabular}




\begin{tabular}{lll}
\hline Variable & No. of Items & Source \\
\hline Adoption of e-banking & 6 & Boateng et al., 2016; Damghanian et al., \\
& & 2016; Hettiarachchi, 2013; Jayasiri et al., \\
& 2015; Kariyawasam \& Jayasiri, 2015 \\
\hline
\end{tabular}

Five-point Likert scale figures starting from strongly agree (5), agree (4), not sure (3), disagree (2) and strongly disagree (1), have been used here and converted to high, medium and low values. The composite values calculated by using SPSS in between 1-2.33, considered as low; 2.34-3.66, as medium; 3.67-5, as high. The IBM SPSS 20 package was utilized for data analysis of the research.

\section{Assessment of Validity}

Content validity is ensured through literature review and integrating the concerns raised by the e-banking experts in several leading private commercial banks in Sri Lanka. Construct validity is an important characteristic which is concerned with the extent to which a particular measure relates to other measures consistent with theoretically derived hypotheses concerning the concepts (or constructs) that are being measured (Blomberg et al., 2008; Brown et al., 1996; Cronbach \& Meehl, 1955; Wieland et al., 2017). Convergent and discriminant validity are the two subtypes of validity that constitutes construct validity. The current study ensures both convergent and discriminant validity. Reliability of the scale is ensured via Cronbach's alpha.

\section{Results}

The upshot of the data analysis is reported in the first part of this results section. The sample of the study consisted of a higher proportion of male respondents (54.1 percent) than female respondents (45.9 percent). Further, majority of respondents being 64.6 percent were advanced level qualified personnel and 10.5 percent of the respondents were qualified as graduates whereas post-graduate and professional qualification holders were recorded as 9.8 percent and 15.1 percent, respectively. In accordance with the age distribution statistics, the vast majority of respondents (65.2 percent) were aged between $31-50$ years where respondents who aged above 50 years percent recorded as 4.9 percent. Given the figures of the analysis 64.9 percent recorded in the income segment in between Rs.50,000/to Rs.74,999/-. Therefore, the demographic characteristic structure of the sample used for the research, is in order to examine the research issue in the specified context as most of the demographic characteristics of the population are replicated to a greater extent by the designated sample of the research study. 
Since the PTES is a latent variable that could not be directly observed (rather inferred from other variables that could be measured directly), principal component analysis (PCA) was conducted at the onset of the study. PCA was conducted on the 24 items of PTES with orthogonal rotation (varimax). The Kaiser-Meyer-Olkin (KMO) measure verified the sampling adequacy for the analysis, $\mathrm{KMO}=.91$ ('superb' as stated by Field, 2017), and all KMO values for individual items were $>.7$, which is well above the acceptable limit of .5 (Field, 2009). Bartlett's test of sphericity $\chi^{2}, p<.001$, indicated that correlations between items were sufficiently large for PCA. An initial analysis was run to obtain eigenvalues for each component in the data. Four components had eigenvalues over Kaiser's criterion of 1 and in combination explained $50.9 \%$ of the variance. The scree plot was somewhat ambiguous and showed inflexions that would justify retaining both components 2 and 4 . Given the sample size, and the convergence of the scree plot and Kaiser's criterion on four components, four is the number of components that were retained in the final analysis. Table 2a shows the factor loadings after rotation. The items that gather on the same components suggest that component one represents perceived bank attributes, component two perceived E-SQ attributes, component three perceived privacy and component four perceived e-banking website security.

Although several studies have not included the adoption of electronic banking variable and perceived usefulness variable related factor loadings, for the completion of presenting the output of the analysis, researchers have included the same (Al-Sharafi et al., 2018; Al-Sharafi et al., 2016; Boateng et al., 2016; Damghanian et al., 2016; Wang et al., 2015; Yousafzai et al., 2003). Consequently, the items that gather on the same components suggest that component one represents time saving and component two represents utility, respectively in relation to perceived usefulness variable (table 2 a middle part). Similarly, as indicated at the bottom of the table $2 \mathrm{a}$, factor loadings in relation to e-banking adoption were gathered into a single component which was named as 'component 1 ' in the given table. All the items connected to e-banking adoption variable consisted of user's past usage and expected utilization of e-banking services. 
Table 2a: Summary of PCA results $(N=305)$

\begin{tabular}{|c|c|c|c|c|}
\hline \multirow[b]{2}{*}{ Item } & \multicolumn{4}{|c|}{ Rotated factor loading for PTES } \\
\hline & $\begin{array}{l}\text { Perceived } \\
\text { bank } \\
\text { attributes }\end{array}$ & $\begin{array}{l}\text { Perceived } \\
\text { E-SQ } \\
\text { attributes }\end{array}$ & $\begin{array}{l}\text { Perceived } \\
\text { privacy }\end{array}$ & $\begin{array}{l}\text { Perceived } \\
\text { e-banking } \\
\text { website } \\
\text { security } \\
\end{array}$ \\
\hline $\begin{array}{l}\text { I believe that my bank is very } \\
\text { large bank }\end{array}$ & .82 & & & \\
\hline $\begin{array}{l}\text { I believe that my bank is one of } \\
\text { the largest in the banking industry }\end{array}$ & .70 & & & \\
\hline $\begin{array}{l}\text { I believe that my bank handles } \\
\text { very large no. of transactions per } \\
\text { day }\end{array}$ & .67 & & & \\
\hline $\begin{array}{l}\text { I believe that my bank handles } \\
\text { very large value of transactions } \\
\text { per day }\end{array}$ & .66 & & & \\
\hline $\begin{array}{l}\text { I believe that my bank has a very } \\
\text { good reputation within the } \\
\text { banking sector }\end{array}$ & .63 & & & \\
\hline $\begin{array}{l}\text { I believe that my bank has a very } \\
\text { good reputation among the } \\
\text { general public }\end{array}$ & .61 & & & \\
\hline $\begin{array}{l}\text { I believe that my bank is } \\
\text { trustworthy }\end{array}$ & .58 & & & \\
\hline $\begin{array}{l}\text { I believe that my bank is customer } \\
\text { oriented }\end{array}$ & .55 & & & \\
\hline $\begin{array}{l}\text { I am able to access the electronic } \\
\text { banking (EB) website quickly }\end{array}$ & & .79 & & \\
\hline $\begin{array}{l}\text { I am able to quickly complete } \\
\text { transactions through the bank's } \\
\text { web site }\end{array}$ & & .75 & & \\
\hline $\begin{array}{l}\text { I am able to use the EB } \\
\text { utilities/related facilities, of } \\
\text { website without lot of effort }\end{array}$ & & .71 & & \\
\hline $\begin{array}{l}\text { The EB website is always } \\
\text { available for customers for } \\
\text { transactions }\end{array}$ & .63 & .70 & & \\
\hline $\begin{array}{l}\text { My bank's customer services are } \\
\text { easily accessible }\end{array}$ & & .66 & & \\
\hline $\begin{array}{l}\text { My bank's website has the } \\
\text { services of customer service } \\
\text { representatives who are available } \\
\text { online }\end{array}$ & & .65 & & \\
\hline $\begin{array}{l}\text { My bank offers prompt responses } \\
\text { to customer requests }\end{array}$ & & .59 & & \\
\hline $\begin{array}{l}\text { My bank quickly resolves online } \\
\text { transaction problems }\end{array}$ & & .57 & & \\
\hline
\end{tabular}




\begin{tabular}{|c|c|c|c|c|}
\hline \multirow[b]{2}{*}{ Item } & \multicolumn{4}{|c|}{ Rotated factor loading for PTES } \\
\hline & $\begin{array}{l}\text { Perceived } \\
\text { bank } \\
\text { attributes }\end{array}$ & $\begin{array}{l}\text { Perceived } \\
\text { E-SQ } \\
\text { attributes }\end{array}$ & $\begin{array}{l}\text { Perceived } \\
\text { privacy }\end{array}$ & $\begin{array}{l}\text { Perceived } \\
\text { e-banking } \\
\text { website } \\
\text { security }\end{array}$ \\
\hline $\begin{array}{l}\text { My bank does not misuse } \\
\text { customers' personal information }\end{array}$ & & & .87 & \\
\hline I feel safe in EB transactions & & & .79 & \\
\hline $\begin{array}{l}\text { My bank does not share personal } \\
\text { information with other websites }\end{array}$ & & & .74 & \\
\hline $\begin{array}{l}\text { My bank uses precautions to } \\
\text { avoid misuse and ensures security } \\
\text { and safety of customer data }\end{array}$ & & & .71 & \\
\hline My bank has a sound process for & & & & .73 \\
\hline $\begin{array}{l}\text { EB user authentication related to } \\
\log \text { in }\end{array}$ & & & & \\
\hline $\begin{array}{l}\text { My bank has a sound process for } \\
\text { EB user authentication related to } \\
\text { transactions }\end{array}$ & & & & .68 \\
\hline $\begin{array}{l}\text { My bank handles personal and } \\
\text { financial data confidentially }\end{array}$ & & & & .65 \\
\hline $\begin{array}{l}\text { My bank always upholds secrecy } \\
\text { of customer data }\end{array}$ & & & & .61 \\
\hline Eigen values & 7.32 & 1.91 & 1.32 & 1.24 \\
\hline Percentage of variance & 31.40 & 7.91 & 5.82 & 5.77 \\
\hline
\end{tabular}

Item

Rotated factor loading for PU

\begin{tabular}{|c|c|c|}
\hline $\begin{array}{l}\text { I believe that EB services enhances my } \\
\text { productivity }\end{array}$ & .83 & \\
\hline $\begin{array}{l}\text { I believe that EB services enables me to } \\
\text { use banking services quickly }\end{array}$ & .82 & \\
\hline $\begin{array}{l}\text { I believe that EB usage increases my } \\
\text { efficiency }\end{array}$ & .79 & \\
\hline $\begin{array}{l}\text { I believe that EB use has increased } \\
\text { effectiveness in attending to financial } \\
\text { requirements }\end{array}$ & .74 & \\
\hline Usage of EB has resulted in saving time & .72 & \\
\hline Use of EB has lot of practicality & & .96 \\
\hline $\begin{array}{l}\text { EB assists to get done immediate } \\
\text { banking transactions }\end{array}$ & & .93 \\
\hline $\begin{array}{l}\text { EB suits to fulfill instant financial } \\
\text { inquiries }\end{array}$ & & .87 \\
\hline EB financially worthwhile & & .85 \\
\hline EB offers lot of convenience & & .81 \\
\hline
\end{tabular}




\begin{tabular}{|c|c|}
\hline \multicolumn{2}{|c|}{ Rotated factor loading for adoption of e- banking } \\
\hline Item & Component 1 \\
\hline $\begin{array}{l}\text { During last } 30 \text { days I have frequently } \\
\text { adopted EB }\end{array}$ & .94 \\
\hline $\begin{array}{l}\text { During last } 30 \text { days I have used EB for } \\
\text { all my banking needs }\end{array}$ & .91 \\
\hline My adoption for EB is a good idea & .88 \\
\hline $\begin{array}{l}\text { My adoption for EB is a pleasant } \\
\text { experience }\end{array}$ & .81 \\
\hline $\begin{array}{l}\text { I have already planned to use EB for } \\
\text { next six months }\end{array}$ & .75 \\
\hline $\begin{array}{l}\text { I have already planned to use EB for all } \\
\text { my banking needs, for next six months }\end{array}$ & .70 \\
\hline
\end{tabular}

Further findings and possible significances are also discussed in this section in detail. Initially, a reliability analysis was conducted to measure internal consistencies of the total scores for each scale through Cronbach's alpha coefficients. The calculation of reliability measurements is presented in table $1 \mathrm{~b}$. As per the findings, all the reliabilities for three variables-PTES, adoption and adoption of e-banking are found to be adequate since Cronbach's alpha values are higher than 0.7 (George \& Mallery, 2003). Moreover, K-S test and Levene' s test performed to ensure normal distribution of respondents' data and homoscedasticity where results were not significant for both the tests.

Table 2b: Reliability analysis of the variables

\begin{tabular}{lllll}
\hline & No. of items & $\begin{array}{l}\text { Cronbach's } \\
\text { alpha }\end{array}$ & Mean & $\begin{array}{l}\text { Standard } \\
\text { deviation }\end{array}$ \\
\hline PU & 10 & .962 & 4.45 & .44 \\
PTES & 24 & .988 & 3.78 & .63 \\
Adoption of e- banking & 6 & .883 & 4.38 & .56 \\
\hline
\end{tabular}

According to the descriptive statistics as depicted in the table 1, all the composite means of the three variables are at high level as the composite mean figures are all above 3.66 (where 5-point Likert scale figures starting from strongly agree, agree, not sure, disagree and strongly disagree, have been converted to high, medium and low values in the following manner, 1-2.33, low; 2.34-3.66, medium; 3.67-5, high, respectively). Composite mean of the PU variable was 4.45. There were six constructs for the PTES and subsequently the composite mean was recorded at 3.78 while the dependent variable; adoption of electronic banking has reported a mean of 4.38 . 
Pearson correlation analysis was performed in order to determine the relationship between adoption of e-banking with two independent variables and correlation matrix of the variables, is presented in table 2. Results of the analysis revealed that the adoption of e-banking possesses a positive relationship with both PTES and PU variables whilst both the relationships were significant at .01 level (1tailed). The highest correlation coefficient figure $(\mathrm{r}=.916)$ was reported between adoption of e-banking and PU variables. Result denotes that in order to improve the degree of adoption of e-banking, it is vital to focus attention and promote PU and PTES characteristics namely perceived bank attributes, perceived e-service quality attributes, perceived privacy and perceived e-banking website security dimensions. Furthermore, findings reinstated that both the directional hypotheses are supported by empirical evidence and could be established that the adoption of e-banking is positively correlated with both the PU and PTES characteristics in the context of topmost private commercial banks in Sri Lanka.

Table 3: Correlation matrix

\begin{tabular}{|c|c|c|c|}
\hline & $\begin{array}{l}\text { Adoption of e- } \\
\text { banking }\end{array}$ & PTES & $\mathbf{P U}$ \\
\hline Adoption of e- banking & 1 & & \\
\hline PTES & $.873^{* *}$ & 1 & \\
\hline PU & $.916^{* *}$ & $.845^{* *}$ & 1 \\
\hline
\end{tabular}

A multiple regression analysis was conducted using hierarchical method (each set of summary statistics is repeated at each stage of the hierarchy) to predict the degree to which independent variables; adoption and PTES impact the adoption of electronic banking (Table $3 \mathrm{a}$ and Table $3 \mathrm{~b}$ ). In accordance with model 1 (Table $3 a)$, the overall variance of e-banking adoption explained by PTES is $76.2 \%$ as per the adjusted R square figure. According to the significance value, model 1 is statistically significant.

Table 4a: Regression output and coefficients

\begin{tabular}{llllllll}
\hline & $\boldsymbol{t}$ & Sig. & $\boldsymbol{\beta}$ & $\begin{array}{l}\boldsymbol{F} \\
\text { Change }\end{array}$ & $\boldsymbol{d f}$ & $\begin{array}{l}\text { Sig. } \boldsymbol{F} \\
\text { Change }\end{array}$ & Adj. $\boldsymbol{R}^{\mathbf{2}}$ \\
\hline Model 1 & & & & 974.68 & 1 & .000 & .762 \\
(Constant) & 27.74 & .000 & 2.110 & & & & \\
PTES & 31.22 & .000 & 0.620 & & & & \\
\hline
\end{tabular}

Dependent variable: Adoption of e-banking

Predictors: (Constant), PTES

In accordance with model 2 (Table $3 \mathrm{~b}$ ), the overall variance of e-banking adoption explained by PTES and PU is $87.2 \%$ as per the adjusted R square figure. 
According to the significance value, model 2 is also statistically significant. As the beta values and $t$ statistics imply, considering the strength of the influence of each independent variable on adoption of e-banking, the PU dimension is the largest contributor with $16.22 \mathrm{t}$ and .496 beta coefficient statistics, respectively. Furthermore, it is evident that both PU and PTES variables positively influence the adoption of e-banking given the positive beta coefficient values and significance of same. Improvement from the model 1 to model 2 can be seen while observing the F change and R square change with the addition of PU variable in addition to PTES variable. For the model $1 \mathrm{~F}$ change is 974.68 and for the model 2 it is 262.99 in which both are significant. Similarly, explanation of adoption of e banking only by PTES was $76.3 \%$ and with the addition of PU variable same has been increased to $87.3 \%$ reporting an $\mathrm{R}$ square change of $11 \%$.

Table 4b: Regression output and coefficients

\begin{tabular}{llllllll}
\hline & $\boldsymbol{t}$ & Sig. & $\boldsymbol{\beta}$ & $\begin{array}{l}\boldsymbol{F} \\
\text { Change }\end{array}$ & $\boldsymbol{d f}$ & $\begin{array}{l}\text { Sig. } \boldsymbol{F} \\
\text { Change }\end{array}$ & Adj. $\boldsymbol{R}^{\mathbf{2}}$ \\
\hline Model 2 & & & & 262.99 & 1 & .000 & .872 \\
(Constant) & 18.39 & .000 & 1.343 & & & & \\
PTES & 09.09 & .000 & 0.247 & & & & \\
PU & 16.22 & .000 & 0.496 & & & & \\
\hline
\end{tabular}

Dependent variable: Adoption of e-banking

Predictors: (Constant), PTES, PU

For the current model the VIF and Tolerance values recorded as 3.498 and .286 which are well below 10 and above 0.2 subsequently; therefore, it could be safely concluded that there is no collinearity within the data. Even the average VIF which is also 3.498 is not substantially greater than 1 which also shows that there is no cause for concern. In order to determine the cases which are influencing the regression model, case-wise diagnostics were checked where any case (standardized residual) with $\mathrm{Z}$ value above/below +/-3.29 was not found which could have been an outlier. All the values of the Cook's distance also reported below 1 (case with maximum Cook's distance value is .035) indicating that there are no cases that are influencing the regression model. Also, there were no values greater than twice or three times the average leverage value $(0.01)$ and all the cases are within the boundaries of 0.97 and 1.03. From the guidelines for the Mahalanobis distance it was identified that if the sample is 100 with 3 predictors; crudely, values greater than 15 were problematic. However, in this study of 305 respondents with 2 predictors there were no values greater than 15 (case with maximum Mahalanobis distance value is 5.57). Further, DFBeta statistics could be examined to identify any case with a large influence on the regression 
parameters. An absolute value greater than 1 is problematic and in all the cases values lie within $+/-1$, which demonstrates that these cases have no undue influence over the regression parameters. Similarly, upper and lower boundaries of covariance ratio were calculated as 1.03 and 0.97 respectively. Cases that are outside these limits could be problematic where none of the cases have been found outside the limits which cause no alarms for deviations (case with lowermost covariance ratio reported a value of 0.9784 and case with topmost covariance ratio reported a value of 1.0282 ).

In order to generalize the model beyond the sample, it is necessary to check some of the assumptions of regression residuals. If the graph of standardized residuals (ZRESID) plotted against standardized predicted values of the dependent variable (ZPRED) looks like a funnel or dots have a curved shaped pattern then it may be violating the assumptions of homogeneity or linearity. If the dots seem to have a pattern and are more spread out at some points on the plot than others, then there could be violation of both homogeneity of variance and linearity. Any of these scenarios puts the validity of the model into a question. Nevertheless, in this instance dots looked like a random array of dots which showed the normality and linearity of residuals. Furthermore, histograms looked like normally distributed and P-P plot looked like curving around a diagonal line which is supportive for generalizing the model beyond the sample. Therefore, it could be summarized that the model appears in most senses to be both accurate for the sample and generalizable to the population of interest as the assumptions have been met and could be safely assumed that this model would generalize to adoption of ebanking in Sri Lanka.

An independent t test was conducted by separating the sample into male and female customers to examine whether there are differences or similarities exist among the two gender categories of the sample. According to the independent $t$ test group statistics given in Table 4, there is a difference between e-banking adoption among males (mean $=4.5515)$ and female customers $($ mean $=4.3345)$. Hence, the mean value of e-banking adoption for males is greater than their female counterparts as per the results shown in the table.

Table 5: Group statistics

\begin{tabular}{llllll}
\hline & Gender & N & Mean & $\begin{array}{l}\text { Std. } \\
\text { Deviation }\end{array}$ & $\begin{array}{l}\text { Std. Error } \\
\text { Mean }\end{array}$ \\
\hline $\begin{array}{l}\text { Adoption of } \\
\text { e-banking }\end{array}$ & Male & 165 & 4.5515 & .4155 & .0324 \\
\hline
\end{tabular}


According to the analysis results depicted in the Table 5, difference in the mean values of e-banking adoption is statistically significant since the $P$ value is less than 0.5 ( $P$ value $=.009)$. Consequently, female customers' mean e-banking adoption is comparatively less than males. In order to determine the effect size, coefficient correlation could be computed using the given $t$-statistic and same is calculated as .24 reporting a lower size effect on adoption of e-banking by males and females.

Table 6: Independent sample t test

\begin{tabular}{cccc}
\hline & $\boldsymbol{t}$ & df & Sig. (2-tailed) \\
\hline Adoption of e-banking & 4.371 & 303 & .000 \\
\hline
\end{tabular}

Illustration of relationship among demographic variables and adoption of ebanking is captured in Table 6a. One-way analysis of variance (ANOVA) was executed with the purpose of testing whether there are differences between age, education, occupation, banking experience and adoption of e-banking. Accordingly, it was noticed that there are significant differences exists among all the aforesaid demographic variables since the $P$ values of all the given variables are less than 0.5. Furthermore, a Turkey post-hoc test revealed that the highest occupation category: senior managers and highest in banking experience category: more than 15 years category, possesses more e-banking adoption as against other occupation and less than 5 years banking experience categories, respectively.

Table 7a: One-way analysis of variance results (ANOVA)

\begin{tabular}{llllll}
\hline & $\begin{array}{l}\text { Sum of } \\
\text { Squares }\end{array}$ & df & $\begin{array}{l}\text { Mean } \\
\text { Square }\end{array}$ & F & Sig. \\
\hline Age & 15.188 & 2 & 7.594 & 51.034 & .000 \\
Education & 19.075 & 3 & 6.358 & 46.618 & .000 \\
Occupation & 47.514 & 3 & 15.838 & 377.917 & .000 \\
Banking Experience & 23.038 & 3 & 7.679 & 62.322 & .000 \\
Income & 36.638 & 2 & 19.319 & 271.499 & .000 \\
\hline
\end{tabular}

In order to examine the specific hypothesis stated as, there are differences between lower income group and higher income groups, one-way ANOVA with planned contrasts. Each contrast compared two 'chunks' of variance. (A chunk can contain one or more groups.) The first contrast is normally the experimental groups vs. control groups (lower income group; Rs.25,000/- - Rs.49,999/- and higher income groups: middle income Rs.50,000/- - Rs.74,999/- and high income Rs.75,000/- and above). To form the next contrast, took one of the chunks that 
contained more than one group (higher income group) and divided it into two chunks (middle income and high income). Then, end up with one less contrast than the number of experimental conditions. In each contrast, assigned a 'weight' to each group that is the value of the number of groups in the opposite chunk in that contrast. For a given contrast, randomly selected one chunk, and for the groups in that chunk change their weights to be negative numbers. Results are as shown in the Table $6 \mathrm{~b}$ and Table $6 \mathrm{c}$.

There was a significant effect of income on adoption of e-banking, $F(2,302)=$ $271.50, p<.05, \omega=.80$. Secondly, there was a significant linear trend, $F(1,302)$ $=508.70, p<.01, \omega=.77$, indicating that as the income increases, adoption of ebanking increases proportionately. Finally, planned contrasts revealed that having a higher income significantly increased adoption of e-banking compared to having a lower income, $t(302)=23.03, p<.05$ (1-tailed), $r=.79$, and that having a high income significantly increased adoption of e-banking compared to having a middle income, $t(302)=11.05, p<.05$ (1-tailed), $r=.53$.

Table 7b: One-way ANOVA-Trend analysis results

\begin{tabular}{|c|c|c|c|c|c|c|}
\hline & & $\begin{array}{l}\text { Sum of } \\
\text { Squares }\end{array}$ & df & $\begin{array}{l}\text { Mean } \\
\text { Square }\end{array}$ & $F$ & Sig. \\
\hline \multicolumn{2}{|c|}{ Between Groups (Combined) } & 38.638 & 2 & 19.319 & 271.499 & .000 \\
\hline \multirow[t]{3}{*}{ Linear Term } & Unweighted & 36.198 & 1 & 36.198 & 508.695 & .000 \\
\hline & Weighted & 37.881 & 1 & 37.881 & 532.353 & .000 \\
\hline & Deviation & .758 & 1 & .758 & 10.646 & .001 \\
\hline \multirow[t]{2}{*}{ Quadratic Term } & Unweighted & .758 & 1 & .758 & 10.646 & .001 \\
\hline & Weighted & .758 & 1 & .758 & 10.646 & .001 \\
\hline Within Groups & & 21.490 & 302 & .071 & & \\
\hline Total & & 60.128 & 304 & & & \\
\hline
\end{tabular}

Table 7c: One-way ANOVA-Contrast test results

\begin{tabular}{lllllll}
\hline & Contrast & $\begin{array}{l}\text { Value of } \\
\text { Contrast }\end{array}$ & $\begin{array}{l}\text { Std. } \\
\text { Error }\end{array}$ & t & df & Sig. \\
\hline Assume equal & 1 & 1.8674 & .08107 & 23.034 & 302 & .000 \\
variances & 2 & .4823 & .04366 & 11.047 & 302 & .000 \\
Does not assume & 1 & 1.8674 & .07842 & 23.813 & 68.922 & .000 \\
equal variances & 2 & .4823 & 02041 & 23.635 & 197.000 & .000 \\
\hline
\end{tabular}

\section{Discussion of Results}

In accordance with the results of PCA, the items that gather on the same components suggested that component one represents perceived bank attributes factor, component two perceived e-service quality attributes factor, component 
three perceived privacy factor and component four perceived e-banking website security factor based on the author's labeling of the factors. Compliant with that it can be noted that those four factors could be measured and arrive for composite figure to determine the PTES variable. Consistent with the empirical results given in preceding section, adoption of consumer electronic banking has been supported by PU and PTES factors in the context of largest private commercial banks in Sri Lanka. Further, results of correlation analysis outcome noted that two aforementioned independent variables were positively correlated with adoption of electronic banking. In addition, there are empirical evidences supporting the positive relationship between $\mathrm{PU}$ and perceived trust of e-services variables on ebanking adoption (Baraghani, 2007 as cited by Rajapakse, 2017; Damghanian et al., 2016; Nayanajith, 2019; Nayanajith et al., 2019e). Therefore, the findings of present research study conform to the previous findings of respective field. Put it differently, general principles associated with adoption of electronic banking, are applicable to the given context the same. Furthermore, main contributor towards adoption of e-banking is PU. Thus, this research is consistent with the leading theory on technology adoption which is commonly known as TAM. According to the regression analysis using hierarchical method, although PU and perceived trust of e-services constructs are governing variables as per the study, there are other factors which were not discussed in this study that impacts the adoption of e-banking. In agreement with previous research studies, independent $t$ test demonstrated that mean e-banking adoption of male customers is greater compared to females (Nayanajith, 2019; Laforet \& Li, 2005; Nayanajith \& Damunupola, 2019b). However, present study additionally revealed that there are significant differences existent within most of the demographic factors as already discussed in the former section. Additionally, this study revealed that long term banking customers and customers who are holding higher level occupations adopt e-banking to a greater extent as against customers with comparatively short-term banking history and those with relatively low-level occupations, in line with empirical evidence.

A research exploring how the demographics and attitudinal variables may assist to explain adoption and use of technology-based products and services grounded on the surveys conducted with probabilistic samples from two culturally distant countries, the USA and Chile suggested that demographic variables do matter when explaining people's willingness to adopt new technology, with education being the most consistent predictor. Furthermore, some of the findings seem to challenge the attitude-behavior consistency implied by conventional theory while 
attitudinal variables are better predictors of pro-technological behavior in the USA, with technology-related insecurity being the most important of four attitudinal dimensions included in the analysis, demographic variables perform as better predictors in Chile, with educational level outperforming age and gender (Parasuraman, 2000; Rojas-Méndez et al., 2017). Similarly, factors such as income levels, internet experience, age and educational level have been recognized as significant determinants of adoption of e-banking in different other country contexts as well (Kolodinsky, 2004; Odumeru, 2012, Poon, 2007; Rajapakse, 2017).

In the same manner, within the Sri Lankan context also, there were numerous studies that were concentrating on effects of demographic variables towards adoption of e-banking/online banking services. A researcher has noted that people who are in the age limit of 23-30 should be given priority while observing that adoption of IT driven banking services by people who are above 55 years (senior citizens) are different from the rest (Abeyrathna, 2015). Several other studies stated that there were significant differences with regard to internet banking adoption considering different age categories, education attainment, type of occupation, among other factors (Nayanajith, 2020a; Jayasiri et al., 2015; Kariyawasam \& Jayasiri, 2015; Nayanajith et al., 2020a). Similarly, some researchers identified that younger generation who are more computer literate are more likely to adopt internet banking whilst identifying differences in considering education levels, inter alia (Premaratne \& Gunathilaka, 2016; Priyangika et al., 2016; Weerasekara \& Abeygunawardhana, 2011). Therefore, current research mainly focused on analyzing the difference in adoption of e-banking services specifically between lower income category customers and higher income category customers in this particular context, being the secondary objective of the study. Accordingly, detail analysis of e-banking adoption differences/similarities in between other demographic variables such as differences of e-banking adoption amongst different age groups/ education groups and etc. was not given special consideration although they were analyzed in general terms.

Finally, planned contrasts test that was conducted to identify the differences/similarities in adoption of e-banking between lower income category customers and higher income category customers revealed that, having a higher income significantly increased the adoption of e-banking compared to having a lower income and that possessing a high income significantly improved adoption of e-banking services compared to having a middle income. 


\section{Conclusion}

Present study was performed to determine and understand the direction of relationship of perceived trust of e-services and PU on acceptance of consumer e-banking in topmost three private commercial banks operating in Sri Lanka. The empirical evidence supported the two hypotheses demonstrating the positive relationships in between e-banking adoption and both perceived trust of eservices factors and PU. Third hypothesis stating that difference in adoption of ebanking between lower income category customers and higher income category was also supported similarly. Research findings are in compliance with previous research evidence and theories related to contemporary technology adoption. Moreover, it was revealed that there are differences between demographic variables viz. age, income, education, occupation, banking experience and adoption of e-banking. Comprehensive analysis revealed that consumer electronic banking adoption is larger for the high-profile longstanding customers with upper job positions. Finally, it was revealed that having a higher income significantly boosted adoption of e-banking as against having a lower income and that having a high income significantly enhanced adoption of e-banking compared to having a middle income. In practical scenario, almost all the top three private commercial banks perform relatively well with the technology advancements which are taking place periodically (Nayanajith et al., 2020b; Nayanajith, 2020a). Nonetheless, banks cannot disregard the threat of fintech companies and innovative start-up businesses which are invading the consumer banking sphere to a greater extent with latest payment and settlement options, QR code-based payments, payment cards and e-money services, blockchain/distributed ledger related services, investment and instant online lending facilities amidst challenging supervisory and regulatory developments. Therefore, marketers of consumer e-banking service providers should capitalize awareness on PEOU and PU dimensions in conjunction with e-service quality, customer innovativeness, online security, privacy, managing risks, developing trust and etc. to reach new customers in more profitable customer segments along with a view to convert light users to frequent users to uplift the effectiveness, performance and overall profitability in the long run while cementing a mutually rewarding relationship for the betterment of the banking industry at large. Research finding is useful for the financial service providers particularly the bank officials, enabling them to execute segmenting, targeting and profiling their customers with the assistance of previously discussed factors alongside differentiation on demographic characteristics. 
Current study is also subjected to several limitations which confine the reliability to generalize the research findings. To begin with, as respondents of the study were the students of the Kelaniya University, it could be possible to obtain different results in the case of conducting the research in another context as the respondents may not exactly replicate the whole Sri Lankan e-banking customers of the selected commercial banks. Since there were restrictions due to time and other resources, future researches could be performed with greater representation of the entire population to validate the research findings in search of diverse findings in different country, cultural and societal contexts. Similarly, different perspectives namely, the bank's point of view alongside the usage of recent and different models on technology adoption in conjunction with different mediators and moderators will incontestably create value for new research studies, in time to come.

\section{Declaration of Conflicting Interests}

The authors declared no potential conflicts of interest with respect to the research, authorship, and publication of this article.

\section{References}

Abeyrathna, B. G. C. M. (2015). A study on the nature of the customers who used IT driven banking services of commercial banks. In Peradeniya Economics Research Symposium (pp. 92-97).

Aboelmaged, M., \& Gebba, T. R. (2013). Mobile banking adoption: an examination of technology acceptance model and theory of planned behavior. International Journal of Business Research and Development, 2(1), 35-50.

Afshan, S., Sharif, A., Waseem, N., \& Frooghi, R. (2018). Internet banking in Pakistan: an extended technology acceptance perspective. International Journal of Business Information Systems, 27(3), 383-410.

Aladwani, A. M. (2001). Online banking: a field study of drivers, development challenges, and expectations. International Journal of Information Management, 21(3), 213-225.

Alalwan, A. A., Dwivedi, Y. K., \& Rana, N. P. (2017). Factors influencing adoption of mobile banking by Jordanian bank customers: Extending UTAUT2 with trust. International Journal of Information Management, 37(3), 99-110.

Al-Sharafi, M. A., Arshah, R. A., Abo-Shanab, E. A., \& Elayah, N. (2016). The Effect of Security and Privacy Perceptions on Customers' Trust to Accept 
Internet Banking Services: An Extension of TAM. Journal of Engineering and Applied Sciences, 11(3), 545-52.

Al-Sharafi, M. A., Arshah, R. A., Herzallah, F. A., \& Abu-Shanab, E. A. (2018). The Impact of Customer Trust and Perception of Security and Privacy on the Acceptance of Online Banking Services: Structural Equation Modeling Approach. International Journal of Industrial Management, 4(1), 1-14.

$\begin{array}{lllll}\text { Annual } & \text { Report } & \text { Relrom }\end{array}$ https://www.sampath.lk/images/annual_reports/ar2018.pdf

Arcand, M., PromTep, S., Brun, I., \& Rajaobelina, L. (2017). Mobile banking service quality and customer relationships. International Journal of Bank Marketing, 35(7), 1068-1089.

Ba, S., \& Pavlou, P. A. (2002). Evidence of the effect of trust building technology in electronic markets: Price premiums and buyer behavior. MIS quarterly, 26(3), 243-268.

Bagozzi, R. P., Davis, F. D., \& Warshaw, P. R. (1992). Development and test of a theory of technological learning and usage. Human relations, 45(7), 659-686.

Bhattacherjee, A. (2001). An empirical analysis of the antecedents of electronic commerce service continuance. Decision support systems, 32(2), 201-214.

Blomberg, B., Cooper, D. R., \& Schindler, P. S. (2008). Business research methods. 2nd ed. Boston, Mass.: McGraw-Hill/Irwin.

Boateng, H., Adam, D. R., Okoe, A. F., \& Anning-Dorson, T. (2016). Assessing the determinants of internet banking adoption intentions: A social cognitive theory perspective. Computers in Human Behavior, 65, 468-478.

Brown, C. R., Moore, J. L., Silkstone, B. E., \& Botton, C. (1996). The construct validity and context dependency of teacher assessment of practical skills in some pre-university level science examinations. Assessment in Education: Principles, Policy \& Practice, 3(3), 377-392.

Central Bank of Sri Lanka. 2018. Annual Report 2017. Retrieved from https://www.cbsl.gov.lk/en/publications/economic-and-financialreports/annual-reports/annual-report-2017.

Central Bank of Sri Lanka. 2019. Annual Report 2018. Retrieved from https://www.cbsl.gov.lk/en/publications/economic-and-financialreports/annual-reports/annual-report-2018.

Chavan, J. (2013). Internet banking-Benefits and challenges in an emerging economy. International Journal of Research in Business Management, 1(1), 19-26.

Chiou, J. S., \& Shen, C. C. (2012). The antecedents of online financial service adoption: the impact of physical banking services on Internet banking acceptance. Behaviour \& Information Technology, 31(9), 859-871. 
Chiu, C. L., Chiu, J. L., \& Mansumitrchai, S. (2016). Privacy, security, infrastructure and cost issues in internet banking in the Philippines: initial trust formation. International Journal of Financial Services Management, 8(3), 240-271.

Chiu, J. L., Bool, N. C., \& Chiu, C. L. (2017). Challenges and factors influencing initial trust and behavioral intention to use mobile banking services in the Philippines. Asia Pacific Journal of Innovation and Entrepreneurship, 11(2), 246-278.

Chong, A. Y.-L., Ooi, K., Lin, B., \& Tan, B. (2010). Online banking adoption: an empirical analysis. International Journal of Bank Marketing, 28(4), 267-287

Commercial Bank of Ceylon PLC. 2018. Annual Report 2017. Retrieved from https://www.combank.net/newweb/images/pdffiles/2018/Commercial_Bank AR-2017.pdf

Cronbach, L. J., \& Meehl, P. E. (1955). Construct validity in psychological tests. Psychological bulletin, 52(4), 281.

Damghanian, H., Zarei, A., \& Siahsarani Kojuri, M. A. (2016). Impact of perceived security on trust, perceived risk, and acceptance of online banking in Iran. Journal of Internet Commerce, 15(3), 214-238.

Davis, F. D. (1989). Perceived usefulness, perceived ease of use, and user acceptance of information technology. MIS quarterly, 13(3), 319-340.

Davis, F. D., Bagozzi, R. P., \& Warshaw, P. R. (1989). User acceptance of computer technology: a comparison of two theoretical models. Management science, 35(8), 982-1003.

Dayal, S., Landesberg, H., \& Zeisser, M. (1999). How to build trust online. Marketing in electronic commerce environments. Journal of Information Technology, 14(1), 319-331.

De Leon, M. V. (2019). Factors influencing behavioural intention to use mobile banking among retail banking clients. Jurnal Studi Komunikasi, 3(2), 118-137.

Deb, M., \& Lomo-David, E. (2014). An empirical examination of customers' adoption of m-banking in India. Marketing Intelligence \& Planning, 32(4), 475-494.

Field, A. (2017). Discovering statistics using IBM SPSS statistics: North American edition. Sage.

Field, A. (2009). Discovering Statistics Using SPSS (3rd ed.). London: Sage Publications Ltd

Gefen, D., 2000. E-commerce: the role of familiarity and trust. Omega:

George, D., \& Mallery, P. (2003). Reliability analysis. SPSS for Windows, step by step: a simple guide and reference. Boston: Allyn \& Bacon, 222, 232. 
Hanafizadeh, P., Keating, B. W., \& Khedmatgozar, H. R. (2014). A systematic review of Internet banking adoption. Telematics and informatics, 31(3), 492510.

Hatton National Bank PLC. 2018. Annual Report 2017. Retrieved from https://www.hnb.net/2017.

Hettiarachchi, H.A.H. (2013). Factors affecting to customer adoption in internet banking, Kelaniya Journal of Management, University of Kelaniya, 2(2): 6887.

Hoffman, D. L., Novak, T. P., \& Peralta, M. (1999). Building consumer trust online. Communications of the ACM, 42(4), 80-85.

Jayasiri, N. K., Gunawardana, K., \& Dharmadasa, P. (2015). Adoption of Internet Banking in Sri Lanka: An Extension to Technology Acceptance Model. In First Asia Pacific Conference on Contemporary Research (APCCR-2015).

Kariyawasam, N. J., \& Jayasiri, N. K. (2015). Awareness and Usage of Internet Banking Facilities in Sri Lanka. International Journal of Scientific Research and Innovative Technology. ISSN, 2313-3759.

Kaushik, A. K., \& Rahman, Z. (2015). Innovation adoption across self-service banking technologies in India. International Journal of Bank Marketing. 33(2), 96-121.

Kolodinsky, J. M., Hogarth, J. M., \& Hilgert, M. A. (2004). The adoption of electronic banking technologies by US consumers. International Journal of Bank Marketing, 22(4), 238-259.

Laforet, S., \& Li, X. (2005). Consumers' attitudes towards online and mobile banking in China. International journal of bank marketing, 23(5), 362-380.

Lee, C. L., \& Lai, S. Q. (2007). Performance measurement systems for knowledge management in high technology industries: a balanced scorecard framework. International Journal of Technology Management, 39(1-2), 158176.

Lymperopoulos, C., \& Chaniotakis, I. E. (2005). Factors affecting acceptance of the internet as a marketing-intelligence tool among employees of Greek bank branches. International Journal of Bank Marketing, 23(6), 484-505.

Malaquias, R. F., \& Hwang, Y. (2016). An empirical study on trust in mobile banking: A developing country perspective. Computers in Human Behavior, 54, 453-461.

Masoud, E., \& Abu Taqa, H. (2017). Factors affecting customers' adoption of ebanking services in Jordan. Information Resources Management Journal (IRMJ), 30(2), 44-60.

Mayer, R. C., Davis, J. H., \& Schoorman, F. D. (1995). An integrative model of organizational trust. Academy of management review, 20(3), 709-734. 
Meihami, B., Varmaghani, Z., \& Meihami, H. (2013). The effect of using electronic banking on profitability of bank. Interdisciplinary Journal of Contemporary Research in Business, 4(12), 1299-131.

Mirza, A. P., Wallstrom, A., Beheshti, M., \& Mirza, O. P. (2009). Internet banking service adoption: private bank versus governmental bank. Journal of Applied Sciences, 9(24), 4206-4214.

Montazemi, A. R., \& Qahri-Saremi, H. (2015). Factors affecting adoption of online banking: A meta-analytic structural equation modeling study. Information \& Management, 52(2), 210-226.

Morgan, R. M., \& Hunt, S. D. (1994). The commitment-trust theory of relationship marketing. Journal of marketing, 58(3), 20-38.

Narware, D. P. (2016). E-banking-challenges \& policy implications. International Journal of Enterprise Computing and Business Systems, 6(2),0109.

Nayanajith, D. A. G. \& Damunupola, K. A. (2019) " E-Service Trustworthiness and Adoption of Online Banking in the Presence of a Moderator: A Relational Study", Journal of Environmental Science, Computer Science and Engineering \& Technology, 8(4), 265-289, DOI: 10.24214/jecet.B.8.4.26589.

Nayanajith, D. A. G. \& Dissanayake, D. M. R. (2019) "E-Banking Adoption in the Context of Innovation and E-Service Quality: A Review on Concepts and Practices", Journal of Environmental Science, Computer Science and Engineering \& Technology, 8(3), 208-221, https://doi.org/10.1108/02652320310457776

Nayanajith, D.A.G. (2019). 'Relationship of Innovation Characteristics on Adoption of Consumer E-Banking in the Context of Top Three Private Commercial Banks in Sri Lanka', ICBI 2019, Kelaniya, 17 October, viewed 21 September 2019, < http://conf.kln.ac.lk/icbi2019/>

Nayanajith, D.A.G. (2020a). Analysis of the Impact of Innovation Characteristics, Perceived Ease of Use on Adoption of E-Banking Among the Students of University of Kelaniya. Sri Lankan Journal of Banking and Finance, 3(1), 2646.

Nayanajith, D. A. G., (2020b). Multivariate Analysis of User Intentions and Actions Towards Acceptance of Tourism Related Technology, Journal of Management and Tourism Research, 3(1), 13-26.

Nayanajith, G., \& Damunupola, K. A. (2019a). Effects of Subjective Norms and Security on Online Banking Adoption: Multilevel Linear Model Analysis. Asian Journal of Multidisciplinary Studies, 2(1), 9-16. 
Nayanajith, G., \& Damunupola, K. A. (2019b). Relationship of Perceived Behavioral Control and Adoption of Internet Banking in the Presence of a Moderator. Asian Journal of Multidisciplinary Studies, 2(2), 30-41.

Nayanajith, G., \& Damunupola, K. A. (2020a). Effects of Perceived Risk and Subjective Norms on Internet Banking Adoption Amongst the Students of University of Kelaniya: A Multilevel Linear Model Analysis. Journal of Business and Technology, 4(1-2), 42-57.

Nayanajith, G., \& Damunupola, K. A. (2020b). Impact of Perceived Behavioral Control on E-learning Adoption. Interdisciplinary Research in Education, 5(1-2), 1-14.

Nayanajith, G., Damunupola, K. A., \& Pastor, C. K. (2020a). Telebanking Adoption Intentions, Actions and Subjective Norms in the Context of Sri Lankan Private Commercial Banks. Southeast Asian Journal of Science and Technology, 5(1), 1-11.

Nayanajith, G., Damunupola, K. A., \& Pastor, C. K. L. (2020b). E-Service Quality, Technology Self-Efficacy and Smart Banking Adoption in Sri Lanka. ASEAN Multidisciplinary Research Journal, 4(1), 25-32.

Nayanajith, G., Damunupola, K. A., \& Ventayen, R. J. (2019a). User Intentions and Actions Towards Adoption of Technology Based Self-Service Banking Services: A MANOVA Analysis. Southeast Asian Journal of Science and Technology, 4(1), 81-88.

Nayanajith, G., Damunupola, K. A., \& Ventayen, R. J. (2019b). Relationship of Perceived Trust and Perceived Ease of Use on Adoption of Computer Aided Learning in the Context of Sri Lankan International Schools. Southeast Asian Journal of Science and Technology, 4(1), 64-74.

Nayanajith, G., Damunupola, K. A., \& Ventayen, R. J. (2019c). Impact of Innovation and Perceived Ease of Use on E-Learning Adoption. Asian Journal of Business and Technology, 2(1), 19-27.

Nayanajith, G., Damunupola, K. A., \& Ventayen, R. J. (2019d). Website Usability, Perceived Usefulness and Adoption of Internet Banking Services in the Context of Sri Lankan Financial Sector. Asian Journal of Business and Technology, 2(1), 28-38.

Nayanajith, G., Damunupola, K. A., \& Ventayen, R. J. M. (2019e). Online Banking Transactions and Mere-Exposure Effect. Online Journal of Technology Innovation, 2(1), 1-11.

Ndubisi, N. O., \& Sinti, Q. (2006). Consumer attitudes, system's characteristics and internet banking adoption in Malaysia, Management Research News, 29(1), 16-27. 
Normalini, M. K., \& Ramayah, T. (2017). Trust in internet banking in Malaysia and the moderating influence of perceived effectiveness of biometrics technology on perceived privacy and security. Journal of Management Sciences, 4(1), 3-26.

Odumeru, J. A. (2012). The Acceptance of E-banking by Customers in Nigeria. World Review of Business Research, 2(2), 62-74.

Parasuraman, A. (2000). Technology Readiness Index (TRI) a multiple-item scale to measure readiness to embrace new technologies. Journal of service research, 2(4), 307-320.

Philip Gerrard, J. Barton Cunningham, (2003) "The diffusion of Internet banking among Singapore consumers", International Journal of Bank Marketing, 21(1), 16-28, https://doi.org/10.1108/02652320310457776

Pikkarainen, T., Pikkarainen, K., Karjaluoto, H., \& Pahnila, S. (2004). Consumer acceptance of online banking: an extension of the technology acceptance model. Internet Research, 14(3), 224-235.

Premarathne, W., and M. M. Gunatilake. (2016); Consumer adoption of internet banking in Sri Lanka Int. J. of Adv. Res. 4 (11). 758-765] (ISSN 2320-5407).

Priyangika, R. D., Perera, M. S. S., \& Rajapakshe, D. P. (2016, December). An empirical investigation on customer attitude and intention towards internet banking: a case of licensed commercial banks in Colombo district, Sri Lanka. In University of Sri Jayewardenepura, Sri Lanka, 13th International Conference on Business Management (ICBM).

Rahi, S. (2015). Moderating role of brand image with relation to internet banking and customer loyalty: a case of branchless banking. The Journal of Internet Banking and Commerce, 20(3), 1-13.

Rajapakse, R. P. C. R. (2017). E-Banking: A Review of Status, Implementation, Challenges and Opportunities.

Rakesh, H. M., \& Ramya, T. J. (2014). A study on factors influencing consumer adoption of internet banking in India. International Journal of Business and General Management, 3(1), 49-56.

Rojas-Méndez, J. I., Parasuraman, A., \& Papadopoulos, N. (2017). Demographics, attitudes, and technology readiness. Marketing Intelligence \& Planning, 35(1), 18-39.

Rotter, J. B. (1967). A new scale for the measurement of interpersonal trust, Journal of personality, 35(4), 651-665.

Rousseau, D. M., Sitkin, S. B., Burt, R. S., \& Camerer, C. (1998). Not so different after all: A cross-discipline view of trust. Academy of management review, 23(3), 393-404. 
Roy, S. K., Balaji, M. S., Kesharwani, A., \& Sekhon, H. (2017). Predicting Internet banking adoption in India: A perceived risk perspective. Journal of Strategic Marketing, 25(5-6), 418-438.

Samar Rahi, Mazuri Abd. Ghani, (2018) "The role of UTAUT, DOI, perceived technology security and game elements in internet banking adoption", World Journal of Science, Technology and Sustainable Development, 15(4), 338-356, https://doi.org/10.1108/WJSTSD-052018-0040

Samar, S., Ghani, M., \& Alnaser, F. (2017). Predicting customer's intentions to use internet banking: the role of technology acceptance model (TAM) in ebanking. Management Science Letters, 7(11), 513-524.

Saunders, M. N. (2011). Research methods for business students, 5/e. Pearson Education India.

Sayar, C., \& Wolfe, S. (2007). Internet banking market performance: Turkey versus the UK. International journal of bank marketing, 25(3), 122-141.

Sekhon, H., Yap, K. B., Wong, D. H., Loh, C., \& Bak, R. (2010). Offline and online banking-where to draw the line when building trust in ebanking?. International Journal of Bank Marketing, 28(1), 27-46.

Selvanathan, M., Tan, P. J., Bow, T. F., \& Supramaniam, M. (2016). The Impact of Cost, Customer Experience, Ease of Use, and Trust towards Adoption of Online Banking. International Business Research, 9(11), 235-241.

Suh, B., \& Han, I. (2002). Effect of trust on customer acceptance of Internet banking. Electronic Commerce research and applications, 1(3-4), 247-263.

Suh, B., \& Han, I. (2003). The impact of customer trust and perception of security control on the acceptance of electronic commerce. International Journal of electronic commerce, 7(3), 135-161.

Sun, B., Sun, C., Liu, C., \& Gui, C. (2017). Research on initial trust model of mobile banking users. Journal of Risk Analysis and Crisis Response, 7(1), 1320.

Vatanasombut, B., Igbaria, M., Stylianou, A. C., \& Rodgers, W. (2008). Information systems continuance intention of web-based applications customers: The case of online banking. Information \& Management, 45(7), 419-428.

Venkatesh, V. (2000). Determinants of Perceived Ease of Use: Integrating Control, Intrinsic Motivation, and Emotion into the Technology Acceptance Model. Information Systems Research, 11(4), 342-365. doi:10.1287/isre.11.4.342.11872 
Wai-Ching Poon, (2007) "Users' adoption of e-banking services: the Malaysian perspective", Journal of Business \& Industrial Marketing, 23(1), 59-69, https://doi.org/10.1108/08858620810841498

Walfried M. Lassar, Chris Manolis, Sharon S. Lassar, (2005) "The relationship between consumer innovativeness, personal characteristics, and online banking adoption", International Journal of Bank Marketing, 23(2), 176-199, https://doi.org/10.1108/02652320510584403

Wang, M., Cho, S., \& Denton, T. (2017). The impact of personalization and compatibility with past experience on e-banking usage. International Journal of Bank Marketing, 35(1), 45-55. doi:10.1108/JJBM-04-2015-0046

Wang, S. W., Ngamsiriudom, W., \& Hsieh, C. H. (2015). Trust disposition, trust antecedents, trust, and behavioral intention. The Service Industries Journal, 35(10), 555-572.

Weerasekara, S., \& Abeygunawardhana, P. K. W. (2011, August). An empirical study on slow and limited adoption of internet banking by Sri Lankan customers. In Industrial and Information Systems (ICIIS), 2011 6th IEEE International Conference on (pp. 404-409). IEEE.

Wieland, A., Durach, C. F., Kembro, J., \& Treiblmaier, H. (2017). Statistical and judgmental criteria for scale purification. Supply Chain Management: An International Journal, 22(4), 321-328.

Yousafzai, S. Y., Foxall, G. R., \& Pallister, J. G. (2010). Explaining internet banking behavior: theory of reasoned action, theory of planned behavior, or technology acceptance model? Journal of applied social psychology, 40(5), 1172-1202.

Yousafzai, S. Y., Pallister, J. G., \& Foxall, G. R. (2003). A proposed model of etrust for electronic banking. Technovation, 23(11), 847-860. 